DOI: https://doi.org/10.31933/dijemss.v2i5

Received: 25 June 2021, Revised: 10 July 2021, Publish: 28 July 2021

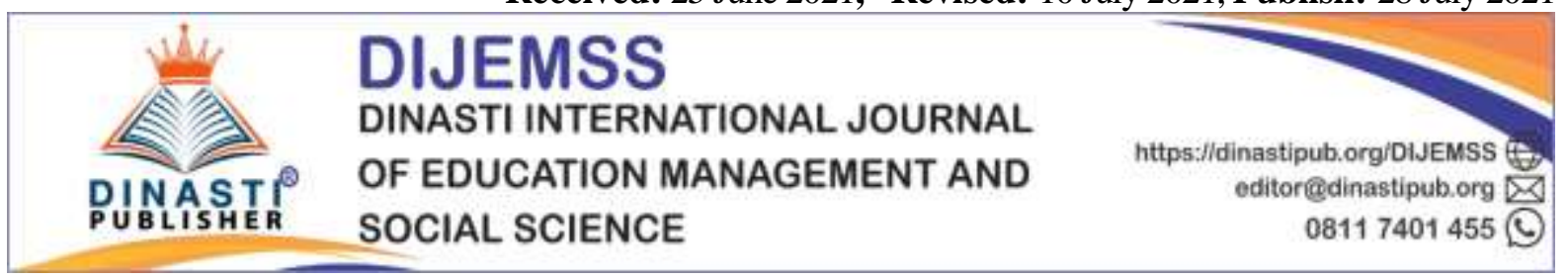

\title{
EFFORTS TO IMPROVE THE TANK CLEANING PROCESS TO SUPPORT THE FAST LOADING OF FUEL OIL IN MT. SUCCESS MARLINA XXXIII
}

\author{
Suhartini Suhartini' ${ }^{1}$, April Gunawan ${ }^{2}$, Rizky Muhammad Adhiwirayuda ${ }^{3}$ \\ 1) Merchant Marine Higher Education, suny.suhartini@gmail.com \\ 2) Merchant Marine Higher Education \\ 3) Merchant Marine Higher Education
}

Corresponding Author: Suhartini

\begin{abstract}
The unpreparedness of the cargo hold tank will result in losses for the company. To produce a truly clean loading space, it is necessary to carry out tank cleaning according to procedures, with adequate infrastructure, planning and good coordination between the parties concerned. The theoretical basis used in this paper describes the procedures for cleaning tanks on appropriate tankers, because delays will cause huge losses for the company. This research is qualitative in nature by conducting interviews and direct observations to see the process of Tank Cleaning activities on the ship so that the method used is a qualitative descriptive method. The type of research contained in the writing of this study is qualitative, namely research by collecting data on the MT ship. Success Marlina 33 then analyzes and draws conclusions in the form of explanations. Based on the results of research conducted at MT.
\end{abstract}

Keywords : Unpreparedness, Tank Cleaning, Deadlines, Claims, Re-Tank Cleaning

\section{INTRODUCTION}

Tanker ship is one of the means of sea transportation from commercial shipping which is a tool to transport liquid cargo or transport petroleum products in large quantities. tankers are also undergoing renewal so that in carrying out the task of operating the ship even more complex.

Personnel are required to be able to adapt themselves and their abilities to existing technology so that they can carry out loading activities properly and correctly. For the smooth operation of ships, especially loading and unloading activities, field operational personnel are needed.

In preparing the ship, especially in the preparation of the tank, of course there have been obstacles, various problems arise regarding the preparation to be carried out, especially when preparing the tank to be loaded with special cargo that should not be contaminated by other objects or cargo. Various cargoes of finished oil have been loaded on the ship mentioned above, 
one of the cargoes to be loaded is Marine Fuel Oil, where the handling of this cargo is one of the most important concerns regarding the readiness and loading of the type itself.

Tank Cleaning is carried out to prevent cargo damage so that the quality of the cargo is guaranteed according to applicable standards. In this case, good and correct Tank Cleaning activities are required to be clean and free of gas before receiving new cargo to be loaded.

In the development of science and technology, tankers are also undergoing renewal so that the implementation of ship operation tasks is increasingly complex. For this reason, officers and crew members $(\mathrm{ABK})$ are required to be able to adapt and adapt to existing technology so that they can carry out loading activities properly and correctly. All of these activities cannot be separated from the expertise and skills of the crew on board, especially the deck crew led by Mualim I.

For the smooth operation of the ship, it is necessary to have field operational personnel, in this case the crew deck who understands and masters their duties, especially a Mualim who is required to be responsible for supervising the loading and tank cleaning processes that are good and efficient.

In loading and unloading activities on tankers containing product oil such as Marine Fuel Oil, in this case it cannot be separated from proper and efficient tank cleaning activities, a very important job before oil is loaded into the tank. Then the tank must be clean and free of gas before receiving the cargo of oil to be loaded.

In the implementation of Tank Cleaning, delays often occur, namely because the time given is too short, the cause is a short distance or the number of loading spaces cleaned is not much, which can lead to claims and re-washing in the loading room after being surveyed It was caused by field personnel working on Tank Cleaning in an inefficient manner and also the lack of knowledge of the crew on proper and correct Tank Cleaning procedures.

In the process of transportation and loading there are rules and procedures issued by the charterer and must be carried out by the ship. These regulations and procedures must be carried out properly by the ship in order to avoid claims from the charterer to support the smooth and safe loading process.

This preparation is very important and must really be considered, especially for different types of cargo, sensitive cargo or sensitive loads to other substances that will be easily damaged, for example MFO. Marine Fuel Oil is one of the fuels used to fuel ships. Therefore, cleanliness and concentration must be properly maintained so as not to be damaged. The compound that occurs can cause an explosion when the MFO is used so that it will cause a hazard that can take the user's life. The cleanliness of the tank can be known if the surveyor has checked each tank and issued a dry certificate. If the surveyor does not issue the certificate then the tank is still not clean and not ready to be loaded.

In carrying out the preparation of the tank, a professional officer is needed and knows the ins and outs of the ship where he works and is supported by skilled crew members so as to be able to prepare a loading room properly because the ship where the author carries out sea practice is a ship chartered by another company, then the ship in which the author carries out sea practice is a ship chartered by another company. -charters must really pay attention to time and must use the minimum time possible well. 
Based on the facts obtained, there were findings, namely the delay and lack of cleanliness of the loading room during the cleaning process from the loading port to the unloading port so that it disrupted the loading and unloading efficiency process. There are several factors that affect the delay in the implementation of tank cleaning and from the analysis of the factors it can be obtained the handling of the delay in loading.

\section{METHOD}

Research is a series of scientific activities in order to solve a problem. Research results are never intended as a direct solution to the problems faced, because research is part of a larger problem solving effort.

According to M. Toha Anggoro (2011: 1.1) Research can be interpreted as a process of collecting and analyzing data or information systematically so as to produce valid conclusions. Research methodology is the way or technique carried out in research. A research must be based on accurate data material so that the results of the research can be accounted for both scientifically and in reality in the field so that the results of the research have a positive value.

According to Sugiyono (2013: 2), the research method is basically a scientific way to obtain data with certain goals and uses. Based on this, there are four keywords that need to be considered, namely the scientific method, data, purpose and usability. According to Darmadi (2013:153), the research method is a scientific way to obtain data with a specific purpose. The scientific method means that research activities are based on scientific characteristics, namely rational, empirical, and systematic. Based on the explanation above, it can be concluded that the research method is a scientific way to obtain data with certain purposes and uses.

According to Azwar (1997:1), the function of research is to find explanations and answers to problems and provide alternatives for possibilities that can be used for problem solving. The relationship that exists between the research subject and the research population is that the population is the whole rather than what is the research subject. Here the author will write that oxygen is the subject of research, while oxygen levels are the population used in the study.

The aim is to break down the particularities that exist into the unique concoction of contexts. The second purpose of sampling is to extract information that will form the basis of the design and emerging theory. Therefore, in qualitative research there is no random sample, but a purposive sample.

The type of research used by the author in this study is descriptive qualitative to describe and describe the object under study. The research method will contain data citations to provide an overview of the data presentation. The data comes from interviews, field notes, photos, personal documents, notes or memos and other official documents. This research is a nonhypothetical research so that in the research there is no need to formulate a hypothesis. Descriptive research that is exploratory in nature aims to describe a phenomenon. Another method used by the author is a qualitative research method which is often called a naturalistic research method because the research is carried out in natural conditions (natural settings).

\section{Approach Method}

Before conducting research, researchers must know the purpose of the research. According to Prof. Dr. Sugiyono (2010:3) there are three types of research objectives, namely those that are discovery, proof and development. Based on chapter I which has been written by the researcher, the purpose of writing this thesis is towards development research. Development 
means deepening and expanding existing knowledge. By knowing the purpose of a study, the author will find it easier to determine the methodology of a study. Because by knowing the research methodology, the author can find out what will be made and how the data from the research will be processed.

In this study, the authors used descriptive research methods; qualitative. This study seeks to explain why a social phenomenon or phenomenon can occur (Nanang Martono: 2010).

The final result of qualitative research is not only to produce data or information that is difficult to find through quantitative methods, but also to be able to produce meaningful information, even hypotheses or new knowledge that can be used to help overcome problems and improve human living standards (Prof. Dr. Sugiyono, 2010). However, in this study the author does not use a hypothesis to solve the problem, this is in connection with the purpose of writing the thesis which is not to create new knowledge or experiments.

\section{Data collection technique}

In compiling this research, the researcher used several data collection methods based on the research writing guidelines that had been provided by the Jakarta Marine Science College campus. The methods used by researchers in this study are as follows:

\section{Observation Techniques (Observation)}

According to Nawawi and Martini (1992:74), "Observation is systematic observation and recording of the elements that appear in a symptom or symptoms on the object of research". This technique is used to obtain a description of the problem and research objectives by observing - direct observation of the improvement of ship services and the problems faced.

2. Library Research (Library Research)

This technique is taken by taking references from relevant theoretical books related to the problems that will be discussed in this thesis. References are taken from several books on the preparation and maintenance of cargo spaces which contain matters relating to the issues raised in this thesis.

3. Documentation Studies

Letters or documents on board for research materials are intended to be used as a complementary means in data collection. The documents that have been read by the author are SOLAS (Safety Of Life at Sea), ISGOTT (International Safety Guide for Oil Tanker Terminal) and STCW (Standard Training Certification and Watchkeeping) which contain the rules that must be carried out by a seafarer.

4. Interview (Interview)

According to Sugiyono (2010: 194), interviews are used as a data collection technique if the researcher will carry out a preliminary study to determine the problems that must be studied, and also researchers want to know things that are more in-depth respondents and the number of respondents is small.

In this study, researchers conducted interviews with operational staff employees and service users of the Jakarta Tanjung Priok Port.

\section{Data analysis technique}

According to Moleong (2007:280-281), "Data analysis is the process of organizing and sorting data into patterns, categories, and basic units of description so that themes can be found and where to formulate working hypotheses as suggested by the data". so that the reader can understand what the author is saying. 
The data analysis technique that the researcher used in this study was descriptive qualitative. According to Manulang (2004:35), descriptive analysis is a method that can be used to examine a group of people, a set of conditions, a system of thought or a class of events in the present.

According to Moleong (1988:6) the data needed in descriptive in the form of words, pictures, and not numbers. From some of the definitions above, it can be concluded that descriptive analysis is a method that can be used to analyze data as clearly as possible so that readers can understand what the author is saying.

\section{RESULTS AND DISCUSSION \\ Lack of understanding of crew members on implementation procedures and use of equipment.}

Lack of knowledge and skills, especially crew members, regarding proper and proper tank cleaning. The initial process before a tanker carries out operations or loading activities is the preparation of the loading room (tank cleaning). This preparation is very important and must really be considered, especially for different types of cargo, sensitive cargo or sensitive loads to other substances that will be easily damaged, for example MFO. MFO is one of the fuels used to fuel ships. Therefore, cleanliness and concentration must be properly maintained so as not to be damaged. The compound that occurs can cause an explosion when the MFO is used so that it will cause a hazard that can take the user's life. The cleanliness of the tank can be known if the surveyor has checked each tank and issued a dry certificate. If the surveyor does not issue the certificate then the tank is still not clean and not ready to be loaded. In carrying out the preparation of the tank, a professional officer is needed and knows the ins and outs of the ship where he works and is supported by skilled crew members so that they are able to prepare a loading room properly because the ship where the author carries out marine practice is a ship chartered by another company chartered must really pay attention to time and must use the minimum time as well as possible.

\section{Less time interval in implementation}

Less time interval in the tank cleaning process. In the tank cleaning process, sufficient time is needed so that the tank cleaning process is carried out to get good and maximum results. However, what was expected was not achieved properly because the shipping route was quite short, which was about 60 hours from the port of unloading to the port where the ship would load. With a total of 10 tanks that are planned to be loaded with MFO, the cleaning process for just 1 tank takes about 5-8 hours so that the tank is completely clean and gets good results. So to clean the existing 10 tanks it takes a normal time of around 50-80 hours, while the sailing time is only 60 hours. So there is very little time to carry out the tank cleaning process. Plus Mualim I and one helmsman, just worked for 2 weeks on the boat. Initially Mualim I worked on a crude oil tanker, which rarely did tank cleaning, and the helmsman, previously worked on a container ship and had never worked on a tanker. This is clearly a burden in itself to carry out a good and timely tank cleaning. As long as the author undergoes sea practice aboard the MT. Suceess Marlina 33, the time needed to carry out tank cleaning is very less. Where to carry out the tank cleaning process it takes sufficient time so that the results can be maximized, but in reality it is not. Therefore, time constraints greatly hampered the implementation of tank cleaning on board the ship. who rarely does tank cleaning, and the helmsman, previously worked on a container ship and had never worked on a tanker. This is clearly a burden in itself to carry out a good and timely tank cleaning. As long as the author undergoes sea practice aboard the MT. 


\section{Lack of supervision during activities}

Unattended planning would mean deviations without any means of preventing them. Therefore, supervision must be fact finding, meaning that the implementation of the supervisory function must find facts about how tasks are carried out in the organization. Supervision must be preventive in nature, which means that the monitoring process is carried out to prevent deviations from occurring. As the description above shows that crew members are sometimes lazy to go down into the tank to spray it, this is due to lack of supervision so that deviations occur. The lack of supervision occurs because the first officer lacks rest. Where during tank cleaning supervision, the first officer must keep watch over the sea. As long as the author undergoes marine practice at MT. Success Marlina XXXIII, the time required to carry out tank cleaning is very less and the tank cleaning process requires sufficient and more time so that the results obtained are maximum and according to the procedure, but in reality it is not. Therefore, the limited time or the short distance to the loading port greatly hampers the implementation of tank cleaning on the ship which causes the results to be not optimal so they are asked to do retank cleaning.

\section{CONCLUSION}

After describing and analyzing various problems that arose in the previous chapters on board the MT. Success Marlina XXXIII, in this case regarding the tank cleaning process on board, it can be concluded on the existing problems in the hope that the intent and purpose of writing this thesis can be seen, namely:

1. The main equipment for tank cleaning activities does not support the running of tank cleaning optimally due to the lack of maintenance on tank cleaning equipment and the lack of spare parts for tank cleaning equipment available on board the ship so that it can cause the implementation of tank cleaning to take longer and less efficiently coupled with lack of trained personnel on board the implementation procedures in accordance with the existing Tank Cleaning Guide.

2. The time interval given by the charterer to the ship for the implementation of Tank Cleaning is relatively short, causing the crew to work under pressure against the given time deadline so that the crew does not carry out the procedures set by the company properly and the crew's lack of discipline causes delays in the loading process. .

\section{BIBLIOGRAPHY}

Anggoro, Toha. 2011. Revised Research Methods. Jakarta: Open University

Marton, GS 2007. Tanker Operation Fifth Edition. England: Mary Land

Moleong, Lexy J. 2006. Qualitative Research Methodology. Bandung: PT Teen Rosdakary

Verweys, DR 2007. Tank Cleaning Guide. Rotterdam

Sugiyono. (2013). Quantitative, Qualitative and R\&D Research Methods. Bandung: Alfabeta.CV

Darmadi Hamid (2013). Educational and social research methods. Bandung : Alphabeta

Sugiyono. 2010. Quantitative, Qualitative, and R\&D Research Methods. Bandung: Alphabeta

Nawawi, Hadari and M. Martini Hadari. 1992. Research Instruments in the Social Sector.

Yogyakarta: Gadjah Mada University Press.

Moleong, J. Lexy. 2007. Qualitative Research Methodology. Bandung: Rosda. 